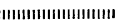

Note

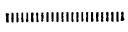

\section{Mode of Controlling Action of Probenazole against Rice Blast Disease with Reference to the Induced Resistance Mechanism in Rice Plant}

\author{
Yasuharu Sekizawa and Sadaaki MaSE* \\ Research Laboratories, Meiji Seika Kaisha, Ltd., Kohoku-ku, \\ Yokohama, Kanagawa 222, Japan \\ * Section of Agriculture, Department of Pharmaceutical Development, \\ Meiji Seika Kaisha, Ltd., Kyobashi, Tokyo 104, Japan
}

(Received August 18, 1980)

Extensive research has been done on the mechanism of action of a nonfungicidal controlling agent, probenazole (Fig. 1), a systemic controlling agent for submerged application against rice plant blast and bacterial leaf blight disease which has as its major mechanism of action the enhancement of the resistant reaction of rice plant. ${ }^{1-4)}$ This work has led greater knowledge on the resistance mechanism of the rice plant, including the production of host antimicrobial substances (chemical barrier) ${ }^{5,6}$ and the formation of lignoides surrounding the invaded host cell (physical barrier). Four active principles having the chemical properties of highly unsaturated fatty acids with antifungal and/or antibacterial activities were isolated as the chemical barrier from a rice plant seedling which had been treated and inoculated with rice blast fungus conidia. One of these active principles was identified with $\alpha$-linolenic acid. The activities of peroxidase, phenylalanine or tyrosine ammonialyase and catechol-o-methyltransferase in rice leaves were all markedly augmented by the inoculation of the conidia after the treatment of probenazole, this reflected the enhanced formation of the lignoid barrier. In pursuit of a solution to a long-standing mystery in this pesticide research laboratory on why plant hormones markedly affected the efficacy of either general fungicides or bacteriocides having in vitro antimicrobial activity, the effects of exogenously applied plant hormones on the occurrence of rice blast disease were thoroughly analyzed. Using a compatible race and cultivar combination it was found that $\mathrm{IAA}^{*}$ or ethylene** was a strong suppressor upon the grade of occurrence of the disease. This efficacy of IAA was evidently counteracted in the presence of abscisic acid (ABA), implying that the ABA was a strong antagonist against IAA in this system. These hormones, however, did not have any in vitro antifungal activity. ${ }^{7)}$ Further, when ABA alone was applied as an antagonist for IAA, the grade of occurrence of the disease became very aggressive and the efficacy of probenazole dicreased. ${ }^{8)}$ From enzymatic experiments in which the peroxidase in rice leaves or leaf pieces was used as a marker enzyme of resistance characteristics, it became evident that the application of IAA or ethylene alone mimicked the augmentation of the activity of peroxidase in rice leaves or leaf pieces by the infection of rice blast fungus. ${ }^{9)}$ The inoculation of rice blast fungus conidia after the application of IAA or ethylene further augmented the peroxidase level in rice leaves. It was confirmed that the augmentation of peroxidase occurred at the lesion site, and that

* IAA $=$ indoleacetic acid.

** Ethrel® (Nissan Chem. Ind.) (2-chloroethylphosphonic acid) was used for the ethylene source. 


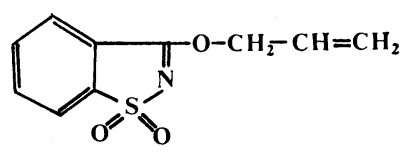

Fig. 1 Structure of probenazole; 3-allyloxy1,2-benzisothiazole-1,1-dioxide.

the augmentation of peroxidase activity was evidently counteracted in the presence of $\mathrm{ABA}$. It was further found that the aseptic cell free extracts of blast fungus conidia obtained by French's press apparently augmented the activity of peroxidase when applied by press injury method. ${ }^{10}$ ) The presence of heat stable and water soluble macromolecular factors responsible for the antigenic action was detected in the cell free extracts. By another experimental run, it was found that the application of IAA or ethylene also mimicked the enhancement of production of host antimicrobial substances in rice leaves by the infection of rice blast fungus. ${ }^{11)}$ It was also recognized that the augmentation of peroxidase activity in rice leaf pieces with the application of IAA or ethylene was inhibited in the presence of cycloheximide, blasticidin $\mathrm{S}$ or formycin $\mathrm{A} .{ }^{9}$

From this evidence, a first physical science model of the signal transmission hypothesis on the resistance mechanism operating in rice plant was proposed under the hypothesis that chemical mediators were linked with the transmission pathway. When rice blast fungus conidium germinates, it forms an appressorium on the surface of the host leaf and stretches the peg (the invading mycelium) from the appressorium penetrating through the cell wall to the surface of the cell membrane around the host cell. The recognition of the antigenic substance of rice blast fungus (described in Scheme 1 as in inducer I for the activation of the resistance mechanism) might occur, accepting the antigenic substance into the receptor which may be located on the surface of the host cell membrane. This invasion process might be quite plausible from microbiological and phytopathological points of view. As the biochemical function of the reverse side of the receptor is still obscure, the function is ascribed to black box $y$. From $y$, the transmission pathway is thought to be

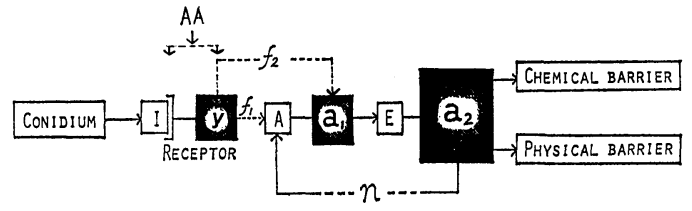

Scheme 1 A first model of the signal transmission hypothesis upon the resistance mechanism of rice plant.

I: Inducer in blast fungus conidium or mycelium. A and E: Chemical mediators. $y, a_{1}$ and $a_{2}$ : Black boxes. $f_{1}$ and $f_{2}$ : Transmission pathway from receptor. $n$ : Negative feed back regulation. AA: Action area proposed for probenazole and its relatives.

connected to a chemical mediator A with black box $a_{1}$ containing $\mathrm{A}$ directed biochemical reactions to produce another chemical mediator, $\mathrm{E}$. The formation of $\mathrm{E}$ in this case then, must be dependent on the formation or presence of $\mathrm{A}$. Thus, the sequence on the transmission pathway(s) might be from A to $\mathrm{E}$, or $Y$ to $\mathrm{A}$ and $\mathrm{E}$. The formation of $\mathrm{E}$ might have an amplifying function in black box $a_{2}$ to form a chemical and physical barrier at and around the host cell invaded by rice blast fungus. This sequence in over-all resistance reaction might be most plausible in the present view of causality of this regard. Based on our present knowledge, the conformability between the lines of experimental evidence and the signal transmission hypothesis (Scheme 1) seems high, if $\mathrm{A}$ is equal to IAA and $\mathrm{E}$ is equal to ethylene in the presence of the Zimmermann-Wilcoxon effect in rice plant. The Zimmermann-Wilcoxon effect bere refers to the IAA-directed ethylene production in the plant, which was established and described over 40 years ago. ${ }^{12,14)}$

As neither probenazole, its degradation products or metabolite ${ }^{15)}$ had any plant hormonal activity in the term of first and second order, ${ }^{1)}$ probenazole does not act as IAA or ethylene. Its action site might be involved in the receptor with black box $y$ because controlling activity decreased in the presence of $\mathrm{ABA}$, as mentioned above. ${ }^{82}$

As described, the resistance reactions including the formation of both chemical and physical barriers, which were derived by the infec- 
tion of rice blast fungus and by the application of IAA or ethylene with or without the inoculation of rice blast fungus, were all counteracted in the presence of $\mathrm{ABA}$ as an antagonist of IAA. This might strongly reinforce the hypothesis that IAA and ethylene participate in the chemical mediation of activation of resistance mechanism in rice plant. This is so even though direct analytical data for the shift of IAA or ethylene at the lesion site during the evoked activation of resistance mechanism are not yet available. Future studies to establish the signal transmission hypothesis relating to black boxes should be done phytopathologically and biochemically. The intriguing assessments might be available from the model (Scheme 1), $a_{1}$ and $a_{2}$ include one that RNA-directed enzyme-protein synthesis, as cycloheximide, blasticidin $\mathrm{S}$ and formycin A inhibits the augmentation of peroxidase activity when IAA or ethylene is applied with or without the inoculation of rice blast fungus. A negative feedback regulation $n$ might include indoleacetate oxidase obtained in a fraction of peroxidase, ${ }^{13)}$ which homeostatically regulated the IAA level. The most intriguing event might be the content of black box $y$. Since tryptophan or methionine was active like IAA or ethylene, respectively, in the above experimental system, ${ }^{11)}$ it might be worthwhile to investigate whether biochemical events in the transmission pathways from receptor, $f_{1}$ and $f_{2}$, are related to the metabolic regulation of tryptophan or methionine. Such reserarch should include studies on the function of an inhibitor protein upon IAA-directed ethylene production which involves the function of host cytoplasmic membrane. ${ }^{14)}$

\section{ACKNOWLEDGMENTS}

The authors wish to express their sincere thanks to Dr. Yasuhiko Uesugi, National Institute of Agricultural Sciences, for his valuable suggestions on the participation of plant hormones in the induction of disease resistance.

The authors are indebted to Dr. T. Watanabe, Head, and all of his colleagues at the Laboratory of Agricultural Biology, Research Laboratories, Meiji Seika Kaisha Ltd., for their support in preparing the manuscript.

\section{REFERENCES}

1) T. Watanabe, H. Igarashi, K. Matsumoto, S. Seki, S. Mase \& Y. Sekizawa: J. Pesticide Sci. 2, 291 (1977)

2) T. Watanabe: J. Pesticide Sci. 2, 395 (1977)

3) T. Watanabe, Y. Sekizawa, M. Shimura, Y. Suzuki, K. Matsumoto, M. Iwata \& S. Mase: J. Pesticide Sci. 4, 53 (1979)

4) M. Iwata, T. Watanabe, Y. Suzuki \& Y. Sekizawa: Ann. Phytopathol. Soc. Jpn. 45, 548 (1979); M. Iwata, Y. Suzuki, T. Watanabe, S. Mase \& Y. Sekizawa: Ann. Phytopathol. Soc. Jpn. 46, 297 (1980)

5) M. Shimura, M. Iwata, N. Tashiro, Y. Sekizawa, Y. Suzuki, S. Mase \& T. Watanabe: Proc. Annu. Meet. Agric. Chem. Soc. Jpn. 3Q-22, 248 (1980)

6) Y. Sekizawa, M. Shimura, A. Suzuki \& M. Iwata: Proc. Annu. Meet. Agric. Chem. Soc. Jpn. 3Q-23, 248 (1980)

7) K. Matsumoto, Y. Suzuki, S. Mase, T. Watanabe \& Y. Sekizawa: Showa-54 Autumn Meet. Phytopathol. Soc. Jpn., Lecture No. 11, at Chiba Univ., 1979; Ann. Phytopathol. Soc. Jpn. 46, 307 (1980)

8) K. Matsumoto, Y. Suzuki, S. Mase, T. Watanabe \& Y. Sekizawa: unpublished.

9) M. Iwata, H. Iwamatsu, Y. Suzuki, T. Watanabe \& Y. Sekizawa: Showa-54 Autumn Meet. Phytopathol. Soc. Jpn., Lecture No. 12, at Chiba Univ., 1979

10) M. Iwata, H. Iwamatsu, Y. Suzuki, T. Watanabe \& Y. Sekizawa: Proc. Annu. Meet. Phytopathol. Soc. Jpn., Lecture No. 1-14, at Tokyo Univ. of Agric., 1980

11) M. Iwata, M. Shimura, N. Tashiro \& Y. Sekizawa: unpublished.

12) A. C. Leopold \& P. E. Kriedemann: "Plant Growth and Development," II Ed., McGrowHill Book Co., N.Y., p. 170, 1975

13) A. C. Leopold \& P. E. Kriedemann: "Plant Growth and Development," II Ed., McGrawHill Book Co., N. Y., p. 114, 1975

14) H. Imaseki \& S. Sakai: Protein, Nucleic Acid and Enzyme, Supplement 76: 2, III-16, 280 (1976)

15) M. Uchiyama, H. Abe, R. Sato, M. Shimura \& T. Watanabe: Agric. Biol. Chem. 37, 737 (1973)

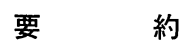

非殺菌性病害防除剤プロベナゾールの作用機 構に関する仮説

関沢泰治, 間瀬定明 非殺菌性病害防除剤プロベナゾールの作用機構研究は 
イネの誘導抵抗性の生化学的解明への系口を与えた. イ ネの病害に対する抵抗反応はいもち病菌分生胞子中にす でに含まれる因子（物質）によって誘発され，病原菌の 侵入した細胞を中心として宿主抗菌性物質の生成（侵入 阻止性化学的障壁の形成) およびリグニン系物質の沈着 集積（伸展阻止性物理的障壁の形成）により終わる一連 の反応であるが，その過程に恒常的制御下にあると考光 られるケミカル・メディエーターが関与していることが 示唆されるに至った. そのメディエーターをIAA およ び IAA 依存下に生成するエチレンとすることで現在得 られている諸実験結果をよく説明しうることがわかって きた。これを統一的にとりまとめ作業仮説として「信号 伝達モデル」を提出した。すなわち, イネいもち病菌胞 子より耐熱性の高分子物質として抵抗性機構を活性化す る因子が得られたので, 病原微生物学的見地から, 宿主
細胞膜上にその受容体があり，この受容体の裏側の機能 がケミカル・メディエーターの生成に関連し， RNA 依 存の酵素蛋白群の生合成が六進し, 被侵入宿主細胞での 化学的ならびに物理的障壁が形成されるとするものであ る.このモデルの適合性を評価し, 確立するには, 今後 多くの病理生化学的実験による証明を要するが，この作 業仮説を得たことによって結果の予想をしながら実験を 導くことが可能となってきた. プロベナゾールおよびそ の分解・代謝物には植物ホルモン活性がないので，その 作用域は受容体およびその裏側の機能に関連して病害抵 抗性を上昇させるものと考えられる.さらに詳しくその 作用点を分子レベルまで解明することはイネの誘導抵抗 性の本態を明らかにするとともに新農薬のデザインに貢 献するものと思われる。 